\title{
AN ASSESSMENT FRAMEWORK TO SUPPORT COLLECTIVE DECISION MAKING ON URBAN FREIGHT TRANSPORT
}

\author{
Ruggero GOLINI ${ }^{*}$, Cindy GUERLAIN ${ }^{2}$, Alexandra LAGORIO ${ }^{3}$, Roberto PINTO $^{4}$ \\ ${ }^{1,3,4}$ Dept of Management, Information and Production Engineering, University of Bergamo, Italy \\ ${ }^{2}$ Dept of IT for Innovative Services, Luxembourg Institute of Science and Technology, Luxembourg
}

Received 16 June 2016; revised 8 November 2016, 15 March 2017; accepted 5 April 2017

\begin{abstract}
This paper proposes a framework that supports the collection and classification of information about the features of a city relevant to Urban Freight Transport (UFT). The information is organized in a framework of 28 different layers that are then stored in a Geographic Information System (GIS) tool to enable efficient data retrieval and effective information graphical display. The resulting GIS tool thus represents a decision support system for UFT problems, providing decision makers and stakeholders with a wide range of easy to understand information aimed to support the identification and preliminary evaluation of UFT solutions. Moreover, by providing a standardized set of features and sources of information, the framework enables the comparison of different cities. To illustrate the benefits, prototypical real-scale tests based on the framework have been realized in two mid-sized European cities: Bergamo (North of Italy) and Luxembourg. For both cities, data were mainly collected from publicly available sources and organized according to the framework. The data and information collected have been used in collaboration with the stakeholders in order to identify the priorities of intervention and evaluate alternative UFT solutions. The real-scale applications confirmed the usability and effectiveness of the framework in engaging stakeholders and support the process of envisioning shared UFT solutions.
\end{abstract}

Keywords: urban freight transport, city logistics, stakeholder engagement, last-mile distribution, GIS, collaboration platform.

\section{Introduction and research background}

Urban Freight Transport (UFT) is one of the major research topics in the field of freight transportation (ERTRAC 2014), as it represents one of the ways indicated by the European Union to increase sustainability and liveability in urban areas (EC 2011).

Many solutions are nowadays available to mitigate the negative impacts of logistics activities in urban contexts (such as congestion, air pollution and noise), and the number is growing every day thanks to the current rates of technological development. The solutions that can be found in the literature vary from regulation (e.g., access restrictions) to time shifts (e.g., off-hour deliveries); from shifts in the transportation technology (e.g., electric vehicles, modal shifts) to changes in the supply chains (e.g., urban consolidation and distribution centres, delivery points for parcels) - Ambrosini, Routhier (2004); Russo, Comi (2011); Cherrett et al. (2012); Benjelloun et al. (2010). According to the databases of projects DOROTHY (Pino et al. 2014) and CIVITAS (Van Rooijen, Quak
2014), the solutions that found larger application belong to six typologies: freight consolidation, modal shift, access restrictions charging and environmental standards, lane and space use, alternative fuels/vehicles, B2C Solutions. These solutions are summarized in Table 1.

Even though many of the aforementioned solutions are quite consolidated, their application is frequently unsuccessful.

A recent systematic literature review in the field (Lagorio et al. 2016), reveals that the main reasons for these failures come from difficulties in retrieving data (Cherrett et al. 2012), uneven regulations, lack of enforcement, obsolete policies (Muñuzuri et al. 2012) and lack of harmonization between the regulations of neighbouring cities (Quak, De Koster 2007). However, the lack of stakeholder involvement - especially in the early stages of the decision making process regarding UFT - is considered as a major source of failure (Dablanc et al. 2011; Dablanc 2007; Lindholm 2014; Lagorio et al. 2016).

*Corresponding author. E-mail: ruggero.golini@unibg.it 
Table 1. UFT solutions, which found larger application in the literature and in practice

\begin{tabular}{|c|c|c|}
\hline Type of solution & Examples & References \\
\hline Freight consolidation & $\begin{array}{l}\text { Urban Consolidation Centres (UCC) / Urban Distribution Centres (UDC) } \\
\text { (e.g., city of Padua) }\end{array}$ & $\begin{array}{l}\text { Olsson, Woxenius (2014); } \\
\text { Stenger et al. }(2013) ; \\
\text { Lindawati et al. (2014); } \\
\text { Alho, Silva (2015) }\end{array}$ \\
\hline Modal shift & Use of naval/railway/airport terminals & Regué, Bristow (2013) \\
\hline $\begin{array}{l}\text { Access restrictions } \\
\text { charging and } \\
\text { environmental standards }\end{array}$ & $\begin{array}{l}\text { Fuel/vehicle type restrictions, limited traffic zones, weight/height/width } \\
\text { restrictions, road pricing, low emission zones, amount and source of noise } \\
\text { (vehicle/handling equipment), night/off-peak deliveries }\end{array}$ & $\begin{array}{l}\text { Quak, De Koster (2009); } \\
\text { Holguín-Veras (2008); } \\
\text { Bjerkan et al. (2014); } \\
\text { Deflorio et al. (2012) }\end{array}$ \\
\hline Lane and space use & $\begin{array}{l}\text { Reserved lanes for transportation, loading-unloading bays optimization, } \\
\text { use parking lots as hub areas }\end{array}$ & $\begin{array}{l}\text { Anderson et al. (2005); } \\
\text { Yang, Moodie (2011); } \\
\text { McLeod, Cherrett (2011); } \\
\text { Flamini et al. (2011) }\end{array}$ \\
\hline Alternative fuels/vehicles & Use of low emissions, electric vehicles and bike delivery & $\begin{array}{l}\text { Gruber et al. }(2014) \text {; } \\
\text { Schneider et al. }(2014) \text {; } \\
\text { Wang et al. }(2014) ; \\
\text { Walker, Manson (2014) }\end{array}$ \\
\hline B2C solutions & $\begin{array}{l}\text { Use of pick-up shops and parcel lockers for parcel delivery to final } \\
\text { customers }\end{array}$ & $\begin{array}{l}\text { Ducret (2014); } \\
\text { Morganti et al. (2014) }\end{array}$ \\
\hline
\end{tabular}

UFT projects involve a large variety of stakeholders (i.e., traders, transporters, traditional couriers, innovative and "green" transport companies), usually with contrasting interests (Lindawati et al. 2014). Even when all the relevant stakeholders are involved and their interests are aligned, stakeholders might not have all the correct information or skills to understand the nature and complexity of UFT problems, and they often overlook fundamental aspects (Lindholm, Behrends 2012). Moreover, stakeholder involvement requires a long-term perspective, time and effort to maintain interest and commitment and settingup working groups is often fraught with obstacles and difficulties (Lindholm 2014; Witkowski, Kiba-Janiak 2014). It does not come as a surprise that, despite the presence of all the necessary stakeholders, many UFT initiatives do not go beyond the experimental stage.

To overcome these issues, several approaches dealing with stakeholder management have been proposed, e.g. Multi-Actor Multi-Criteria Analysis - MAMCA (Macharis et al. 2014; Gatta, Marcucci 2014) with the aim of evaluating different stakeholders' opinions at an early stage of the decision-making process. However, while trying to bridge and compromise the different stakeholders' interests, these methodologies may fall short in actually engaging the stakeholders, i.e., moving the stakeholders to a proactive and supportive attitude.

As a consequence, the aim of this work is not to replace such methodologies, but rather to complement them with a framework and visual tool designed to inform decision-makers and facilitate early stakeholder engagement in UFT projects.

The paper is organized as follows: first, we describe the structure and the sources of information of the proposed framework, providing a methodology that can be followed in other studies. Afterwards, we present the results of the application of the framework and the related tool on two cities: Bergamo (Italy) and Luxembourg. Finally, we draw the main conclusions and future developments stemming from our study.

\section{Building the framework}

In this paper we propose a framework that supports the collection and classification of information with the aim of enabling the assessment of a city along the most important dimensions related to UFT.

The goal of such a framework is threefold. First, it aims at providing a methodology to gather information relevant to UFT, exploiting publicly available information to the maximum possible extent, in order to overcome the wellknown issue of the lack of data (Nuzzolo et al. 2015).

Next, considering the relevance of the stakeholder commitment with respect to the success of any UFT initiative (Holguín-Veras 2008), the framework aims at fostering and facilitating early stakeholder engagement in UFT projects, thanks to a visual and interactive tool, which draws upon the same previously gathered information.

Finally, the framework enables the possibility to perform comparative assessment between cities by providing common dimensions of evaluation. This is a crucial point as several researchers published in-depth case studies performed on single cities, thus generating a useful library of experiences (e.g., Álvarez, De La Calle 2011; Hesse 2004). Nevertheless, because of lack of a common framework, these case studies are often difficult to compare, as the time frame, data collection methods, and context of the cities are very different.

It follows that the framework proposed in this paper is tailored for a specific solution (Table 1), but it allows a high-level evaluation of a broad spectrum of solutions. 
In order to devise the framework, the following building steps have been followed, as further described in the remainder:

- Step 1: identification of the main features of the city, which are relevant to UFT;

- Step 2: definition of the layers and sources of information;

- Step 3: development of an interactive tool to visualize the features to be used by decision makers and stakeholders.

\subsection{Step 1: Identification of the main features}

There are several features of a city to be analysed for a better understanding of UFT activities and impacts. On the basis of the literature, the most important features are the following:

1) Morphology and historical heritage: size of the area, presence of hills, rivers, canals, waterways that can create natural access barriers or make more difficult the distribution. Moreover, presence and extent of the historical centre that characteristics the higher touristic concentration and narrow streets (Pulawska, Starowicz 2014; Muñuzuri et al. 2005);

2) Population: total population and density, as most dense areas have the highest demand for goods, especially parcels (Gatta, Marcucci 2015);

3) Land use: location of residential, commercial or office zones that affects the demand and typology of goods during the day (Alho, Silva 2015);

4) Infrastructures: roads types, number of roads, roads dimensions, road tolls, which affect accessibility to the city (Lian 2008; Mohajeri et al. 2015);

5) Typology and distribution of commercial activities with different logistics requirements summarized in Table 2 (Kittelson, Lawton 1987; Joubert et al. 2010);

Table 2. Different typologies of commercial activities and the related transportation patterns

\begin{tabular}{|l|l|}
\hline \multicolumn{1}{|c|}{ Type of shop } & \multicolumn{1}{c|}{ Transport pattern } \\
\hline $\begin{array}{l}\text { Commerce bulky items } \\
\text { (furniture, sport equipment, } \\
\text { car, household appliances) }\end{array}$ & $\begin{array}{l}\text { Low frequency, require larger } \\
\text { vehicles }\end{array}$ \\
\hline $\begin{array}{l}\text { Commerce small items } \\
\text { (apparel, accessories, kiosks, } \\
\text { excluding supermarkets) }\end{array}$ & $\begin{array}{l}\text { Medium frequency, suitable to } \\
\text { smaller vehicles }\end{array}$ \\
\hline Food & $\begin{array}{l}\text { High frequency, can require } \\
\text { refrigerated vehicles }\end{array}$ \\
\hline $\begin{array}{l}\text { HORECA (hotel, bar, } \\
\text { restaurant) }\end{array}$ & $\begin{array}{l}\text { Medium/high frequency, can } \\
\text { require refrigerated vehicles }\end{array}$ \\
\hline Health (pharmacies) & $\begin{array}{l}\text { Very high frequency, can } \\
\text { require refrigerated vehicles }\end{array}$ \\
\hline $\begin{array}{l}\text { High value (optician, } \\
\text { jewelleries, excluding banks) }\end{array}$ & $\begin{array}{l}\text { Low frequency, subject to } \\
\text { robberies }\end{array}$ \\
\hline
\end{tabular}

6) Transportation companies and logistics activities location, which represent relevant points of origin of commercial traffic towards the city (Allen et al. 2012; Lüer-Villagra, Marianov 2013);

7) Access restriction measures such as weight restrictions or delivery windows, which affect accessibility of the city centres and concentrate private and commercial traffic in specific hours (Quak, De Koster 2009; Holguín-Veras 2008);

8) Existing UFT infrastructures such as freight terminals, urban consolidation centres.

These different features of the city have been rarely considered together. The reason is that they belong to different fields, such as urban planning, geography, logistics. However, since transportation is a sub-system in the broader city system, our framework proposes to consider these dimensions jointly.

\subsection{Step 2: Definition of the layers and sources of information}

In this second step, for each feature described in Step 1, we identified possible sources of information, giving priority to open data sources to extend the application of the framework to other cities. In particular, we substantially relied on Open Street Map (OSM) that has also the advantage to provide with automatic updates thanks to Application Programming Interface (API) routines. However, further sources have been considered in order to increase the reliability and quality level of the information (e.g., data from public authorities). In this respect, it is impossible to be in any sense exhaustive, since the availability of data and information depends upon the areas and cities considered. The two cases presented at the end of this paper illustrate how the different sources of information can be retrieved and combined.

With a view on making the framework user friendly to stakeholders and harmonized with the sources of data, we reorganized the features identified in Step 1 in 8 categories (Table 3). In this effort, we also followed INSPIRE, a European Directive (EC 2007), which aims at facilitating the sharing of spatial data between public authorities and improving accessibility. For instance, we split infrastructures into two categories: road network and railway network and waterways as the former is a capillary infrastructure while the latter is linear infrastructures (railways, rivers and canals).

Next, for each category we defined a set of layers. For instance, the category "access restrictions" was brokendown in the following layers: delivery windows, limited traffic zones, access restrictions and road barriers.

The final framework comprises of 28 layers, classified in 8 categories. The categories and layers are summarized in Table 3, which also reports potential sources of information. It is possible to underline the sparsity of the sources and the relevance of direct observation, thus supporting the need for a unified way to organize this information. 
Table 3. Information used in the framework and sources

\begin{tabular}{|c|c|c|c|}
\hline Category & Description & Layers & Possible sources \\
\hline Morphology & $\begin{array}{l}\text { Includes layers that serve as a background related } \\
\text { to the morphology of the city, such as the presence of } \\
\text { natural enablers or barriers to urban logistics } \\
\text { (e.g., canals, rivers, hills) }\end{array}$ & Morphology & Google maps (terrain) \\
\hline \multirow{3}{*}{$\begin{array}{l}\text { Administrative } \\
\text { units }\end{array}$} & \multirow{3}{*}{$\begin{array}{l}\text { Related to the information representing municipality } \\
\text { borders and historically relevant areas that may } \\
\text { require careful consideration when UFT plans } \\
\text { are devised }\end{array}$} & Municipality/city borders & OSM \\
\hline & & Historically relevant areas & Municipality development plan \\
\hline & & Neighbourhood/quarters & Municipality development plan \\
\hline \multirow{4}{*}{$\begin{array}{l}\text { Society and } \\
\text { commercial } \\
\text { activities }\end{array}$} & \multirow{4}{*}{$\begin{array}{l}\text { Includes the information regarding the population } \\
\text { density and land use (i.e., green, industrial, } \\
\text { infrastructure, residential, residential/commercial, } \\
\text { and tertiary). Also includes residential rent prices } \\
\text { and information about the location and typology } \\
\text { of commercial activities }\end{array}$} & Population density & Corinne land cover \\
\hline & & Land use & Municipality development plan \\
\hline & & Rent prices & Municipality, websites \\
\hline & & $\begin{array}{l}\text { Shops (further divided as } \\
\text { in Table 2) }\end{array}$ & OSM, municipality survey \\
\hline \multirow[t]{4}{*}{ Road network } & \multirow{4}{*}{$\begin{array}{l}\text { Motor vehicles network (including bus lanes and } \\
\text { other dedicated road), cycle network and pedestrian } \\
\text { network are mapped in this category }\end{array}$} & Motor vehicles network & OSM \\
\hline & & Cycle network & OSM \\
\hline & & Pedestrian network & OSM \\
\hline & & Bus lanes & $\begin{array}{l}\text { Municipality Geographic } \\
\text { Information System (GIS) }\end{array}$ \\
\hline \multirow[t]{4}{*}{$\begin{array}{l}\text { Access } \\
\text { restrictions }\end{array}$} & \multirow[t]{4}{*}{ Access restrictions (or controlled access) schemes } & Delivery windows & $\begin{array}{l}\text { Municipality website, direct } \\
\text { observation }\end{array}$ \\
\hline & & Limited traffic zones & $\begin{array}{l}\text { Municipality website, direct } \\
\text { observation }\end{array}$ \\
\hline & & $\begin{array}{l}\text { Access restrictions } \\
\text { (height/weight/width, } \\
\text { fuel) }\end{array}$ & $\begin{array}{l}\text { Municipality website, direct } \\
\text { observation }\end{array}$ \\
\hline & & Road barriers & $\begin{array}{l}\text { Municipality website, direct } \\
\text { observation }\end{array}$ \\
\hline \multirow{6}{*}{$\begin{array}{l}\text { Transportation } \\
\text { facilities }\end{array}$} & \multirow{6}{*}{$\begin{array}{l}\text { Includes information about all the facilities (except } \\
\text { for roads and railways) supporting the execution } \\
\text { of urban logistics processes. Includes the location } \\
\text { of Liquid Petroleum Gas (LPG) and Compressed } \\
\text { Natural Gas (CNG) stations, as well as electric } \\
\text { vehicles charging points. Further, information about } \\
\text { loading and unloading bays and parking slots. } \\
\text { Finally, the presence of airports is considered in } \\
\text { this category }\end{array}$} & Airports & OSM \\
\hline & & Alternative fuels stations & mylpg.eu, cngeurope.com \\
\hline & & Charging points & openchargemap.org \\
\hline & & Street parking & Municipality GIS \\
\hline & & Loading/unloading bays & $\begin{array}{l}\text { Municipality GIS, direct } \\
\text { observation }\end{array}$ \\
\hline & & Parking lots & $\begin{array}{l}\text { OSM, yellow pages, Google } \\
\text { maps }\end{array}$ \\
\hline \multirow{3}{*}{$\begin{array}{l}\text { Delivery } \\
\text { points and } \\
\text { transportation } \\
\text { companies/ } \\
\text { facilities }\end{array}$} & \multirow{3}{*}{$\begin{array}{l}\text { Includes the location of the main transportation } \\
\text { companies (express couriers and 3PLs) that regularly } \\
\text { deliver the goods in the city. Further, contains } \\
\text { specific logistics infrastructure such as UDC and city } \\
\text { terminals is considered in this category }\end{array}$} & Parcel solutions & $\begin{array}{l}\text { Various websites (couriers, } \\
\text { operators, online retailers) }\end{array}$ \\
\hline & & \begin{tabular}{|l}
$\begin{array}{l}\text { Transportation } \\
\text { companies/couriers }\end{array}$ \\
\end{tabular} & Yellow pages, various databases \\
\hline & & $\begin{array}{l}\text { Logistic infrastructures } \\
\text { (UCD, city terminals) }\end{array}$ & $\begin{array}{l}\text { Municipality GIS, direct } \\
\text { observation }\end{array}$ \\
\hline \multirow{3}{*}{$\begin{array}{l}\text { Railway } \\
\text { network and } \\
\text { waterways }\end{array}$} & \multirow[t]{3}{*}{ Includes data about railway and waterway networks } & Railway network & OSM \\
\hline & & Tram network & OSM \\
\hline & & Water network & OSM \\
\hline
\end{tabular}

\subsection{Step 3: Development of an interactive platform to visualize data and use with the stakeholders}

In order to make the collected information readily available, easily retrievable, and clearly represented, we relied on an online interactive platform (Figure 1). In particular, we used the Smart City Logistics (SCL) platform (http:// iguess-sl.list.lu), a Geographic Information System (GIS) developed by the Luxembourg Institute of Science and
Technology (LIST) (Guerlain et al. 2016). In the platform, we replicated the same category/layer structure of Table 3 .

The advantages of using such a platform are its user friendliness, its online access (i.e., the involved decision makers and relevant stakeholders can check the information and use the platform remotely) and its inter-operability between different systems. Indeed, the user can combine different layers via web services without IT expertise. 


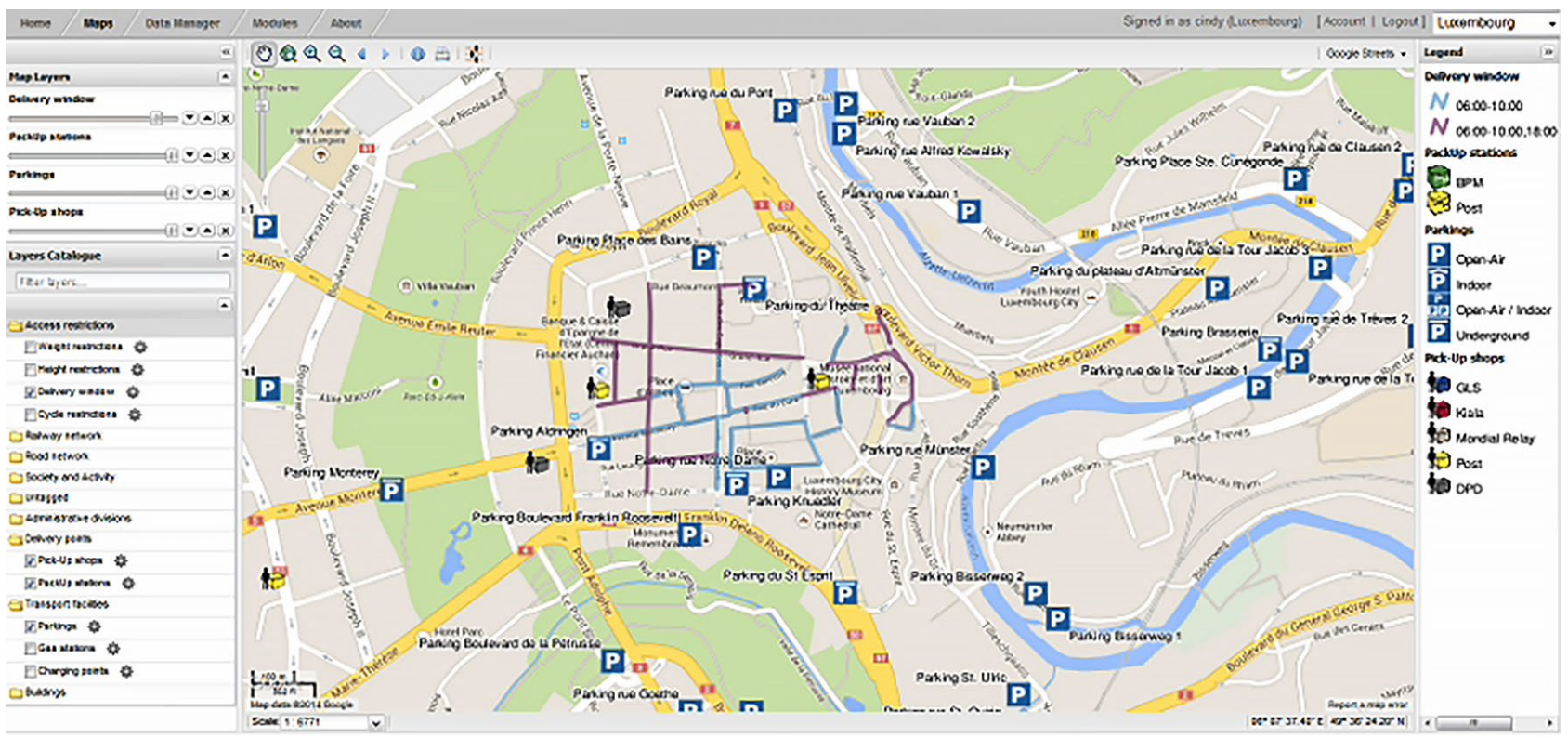

Figure 1. Screenshot from the Smart City Logistics platform (publicly accessible at: http://iguess-sl.list.lu)

\section{Application cases of the framework: Bergamo and Luxembourg city}

In this section, we illustrate the application of the framework and the SCL platform in two mid-size European cities: Bergamo (north of Italy, seat of the province of Bergamo) and the city of Luxembourg (capital of the Grand Duchy of Luxembourg). We demonstrate how the use of a common structure for describing and analyse UFT activities enables an easy comparison between cities. Moreover, we show how the use of the framework through the SCL platform in collaboration with relevant stakeholders can lead to the identification of different priorities of intervention for the two cities. In particular, we show how each layer can be integrated with the others in order to evaluate the applicability of a set of UFT solutions.

The two cities, sharing similar geographical, demographic and infrastructural characteristics (Table 4), have shown increasing interest for UFT issues, and have undergone a process of stakeholder involvement.

Both cities are set up in a hilly landscape: "Città Alta" ("upper city") and part of the "Città Bassa" ("lower city") in Bergamo and Ville-haute ("upper city") and Grund ("lower city") in Luxembourg city compose the historical part of the cities. Both cities are divided in neighbourhoods (7 for Bergamo and 24 for Luxembourg), with different characteristics. In particular, in both cities there are two quarters at the very centre of the city with the highest concentration of commercial activities and services. However, these neighbourhoods are also those with the highest historical relevance, thus more vulnerable to the negative impacts of UFT activities (e.g., noise, pollution, congestion).

The framework has been applied to the cities by two teams of researchers in the two cities between in 2015 . One researcher joined both teams to ensure the consistency in the data collection.

After having collected the data and set-up the platform, several round tables and workshops organized with relevant stakeholders. In Bergamo, the key stakeholders involved were representatives of the municipal council of mobility and transportations, one representative of a large express courier, one representative of the local couriers, one technology provider and one representative of the shop keepers. In Luxembourg, the key stakeholders involved were the Ministry of Sustainable Development

Table 4. Some characteristics of the two case studies (reference year: 2014)

\begin{tabular}{|l|l|l|}
\hline \multicolumn{1}{|c|}{ Characteristic } & \multicolumn{1}{|c|}{ Bergamo (Italy) } & \multicolumn{1}{c|}{ Luxembourg } \\
\hline Morphology/area & $39.6 \mathrm{~km}^{2}$ & $51.73 \mathrm{~km}^{2}$ \\
\hline Morphology/hills & Hilly landscape (min elevation: $211 \mathrm{~m}$; max elevation: $645 \mathrm{~m})$ & $\begin{array}{l}\text { Hilly landscape (min elevation: } \\
232 \mathrm{~m} \text {; max elevation: } 408 \mathrm{~m})\end{array}$ \\
\hline $\begin{array}{l}\text { Morphology/rivers, canals, } \\
\text { waterways }\end{array}$ & No & Yes, but not navigable waters \\
\hline Population/population & 121316 & 107340 \\
\hline Population/population density & $3063 / \mathrm{km}^{2}$ & $2100 / \mathrm{km}^{2}$ \\
\hline Historical heritage/old city & Yes $(10 \%$ of the city area) & Yes $(4 \%$ of city area) \\
\hline
\end{tabular}


and Infrastructure, representatives of the logistics service providers, one representative of the shop-owner association, own account transporters. The tool was used by the stakeholders to envision possible solutions for city logistics. The data collection process and the outcome of the use of the framework are reported in the next paragraphs.

\subsection{Data collection}

The framework provides directions about the potential sources of data and suggests how to classify the information. The collection phase (September 2014 - June 2015), however, remains an extremely time consuming activity aiming to reconstruct a comprehensive picture from sparse contributions.

Considering the two cities of Bergamo and Luxembourg, we relied on the maps provided by Google (Google Terrain) for the morphology, while municipality borders were gathered from OSM using postal codes. However, for the identification of neighbourhood areas and historically relevant areas we needed to access local documentation from the municipalities. Similarly, for the land use layer we needed to access to the municipalities development plan.

Data sources were different between the cities for what concerns renting prices: in Luxembourg, such information was available at the municipality level, while for Bergamo we relied on the data provided by one of the largest Italian online platforms for renting and selling houses.

Information about the location and typology of commercial activities required the use of distinct sources too. While for Luxembourg it was possible to rely on OSM data, for Bergamo there was a clear lack of data about the existing activities, which required to integrate the information with surveys carried out by the municipality.

We divided the commercial activities into different categories according to the nature and/or volume of the goods and related transport (Table 2). For Luxembourg, it was possible to use directly the OSM classification of activities. Thus, a furniture store was classified as dealing with bulky and non-food items, whereas a clothing shop was classified as dealing with small and non-food items. This classification allows the user to better identify potential customers of a logistics initiative. We did exclude supermarkets from the analysis as they have their own distribution systems in place.

Concerning vehicles network, cycle network and pedestrian network, we relied on OSM data that provided reliable information. For the bus lanes instead, we needed direct observations and data from the municipalities.

The information about loading and unloading bays in Bergamo was provided by the public administration while for Luxembourg City it was necessary to retrieve the information via direct inspection. Because of this, for both cities we focused only on a central area with a high density of commercial activities. Data about gas stations and electric vehicle charging station was retrieved from publicly available websites (e.g., mylpg.eu, cngeurope.com, openchargemap.org, plugsurfing.com).
Collecting information about the main transportation companies (express couriers and third party logistic companies) that regularly deliver the goods in the city, was very labour-intensive, as for Luxembourg the market turned out to be very fragmented, while for Bergamo some interviews were needed to understand which companies deliver in the city area.

Finally, neither city has specific logistic infrastructures in place, such as urban consolidation centres or city terminals, and no waterways were found.

In conclusion, although the data collection activity can hardly be standardized, the appreciation of the effort devoted to such activities in a real-scale case underlines the importance of having a proper method to organize the different layers of information.

Finally, the data gathered were uploaded on the SCL platform.

\subsection{Results of the application of the framework and stakeholder engagement}

The platform was well-received by the stakeholders that, after a quick demonstration, became able to directly interact with it. After a more general discussion about the characteristics and problems of the city, the researchers proposed to the stakeholders a set of UFT solutions to be analysed with the support of the platform.

For instance, Figure 2 shows an example of how the combination of the layers was used in the case of Bergamo in order to identify potential locations for an UDC. In the map in Figure 2 are visible the municipality/city borders, the historically relevant areas (Città Alta) and the quarters, which are all potential areas served by a UDC. The map also displays the shops that represent the delivery points and the motor vehicles network for the route calculation, location and accessibility of UDC and served area. Moreover, we can see the zones restricted to vehicles up to 3.5 tons.

From this map, it appeared that the historical centre (Città Alta) has a lot of shops, but a very low accessibility due to access restrictions and transport infrastructures. As a consequence, the stakeholders focused on this area to evaluate the possibility to develop a micro UDC for Città Alta in combination with electric vehicles and cargo bikes. Moreover, in Bergamo, the complex layout of the areas subject to restriction measures became clear to everyone after displaying the information using the SCL platform, while during previous meetings the representatives of transportation companies struggled to explain why this was a major issue for them.

As a result of the interaction with the stakeholders, we could identify the information layers that provide relevant information to the evaluation of different solutions (Table 5). It emerged that some layers are useful only for some solutions while others are more general. For instance, the localization of a freight terminal for modal shifts requires information on all types of infrastructure (water, air, ground transportation facilities) while the other solutions only need the road network. 


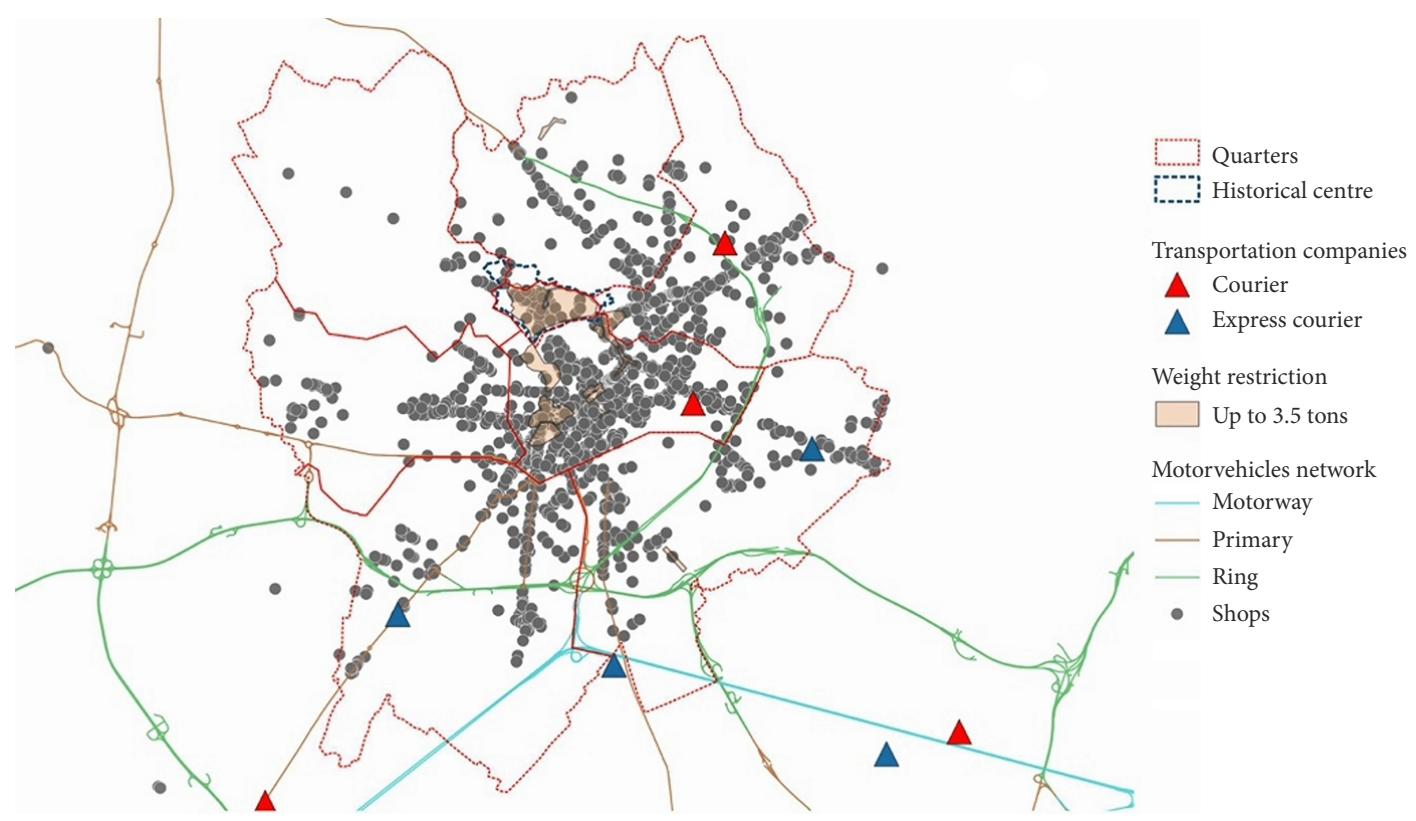

Figure 2. A selection of layers used to evaluate potential locations for a UDC (Bergamo)

It can be seen from Table 5 that the most used layers (at least for 4 out of 6 solutions) are:

- basic terrain map for spatial orientation;

- maps in the administrative units group: in order to identify the geographical limitations of the interventions (i.e., municipality/city borders or neighbourhood/quarters) or the critical areas to serve (i.e., historically relevant areas);

- population density and land use: in order to estimate the level and typology of the demand (for instance, distinguish high/low density residential/office/industrial areas);

- shops, for the same previous reason (estimate level and typology of demand);

- motor vehicles network;

- all the layers in the access restrictions group, to assess the current situation in terms of restricted areas;

- street parking and loading/unloading bays, since parking space near delivery points is necessary to implement almost every type of solution.

With reference to Table 3, all the information for the above-mentioned layers can be easily gathered, except for loading/unloading bays and access restrictions that need to be retrieved from the municipality. However, from the combination of Table 3 and Table 5, future users of this framework can decide whether gather information for all the solutions or focus on one specific solution and gather only the information that is needed. From our experience, we suggest gathering as much information as possible since there are a lot of communalities and synergies in the data gathering process.

After the evaluation of the different solutions, these were prioritized by the stakeholders.

The existence of an historic centre and the hilly morphology emerged as two very relevant factors for both cities. In fact, to preserve historical centres, policy makers define areas with specific delivery windows and the hilly landscapes further limit the accessibility to delivery vehicles. While restrictions can be good in principle, in practice, they often bring to a fragmentation of the deliveries. This problem is particularly evident in Bergamo, where the areas subject to restrictions are many, discontinuous in space and not homogeneous in time. However, also in Luxembourg there are different delivery windows in the streets in the same area, thus leading to potential confusion for transportation companies not accustomed to. These considerations led the stakeholders in both cities to agree on a harmonization of such measures.

In terms of transportation infrastructures, the two cities appear quite similar, but significant differences emerge in terms of typologies of shops: Bergamo has a relevant share of shops in the "commerce small items" category and Luxembourg in the HORECA (food service industry) one. This observation led to the possibility to experiment electric vehicles distribution in Bergamo. Moreover, Luxembourg features a very fragmented market of the transportation companies, thus suggesting the need of a consolidation centre. On the contrary, in Bergamo, where there are already few companies operating, therefore a micro urban consolidation centre could be designed for the parts of the city more difficult to reach and with higher historical value (i.e., Città Alta).

Furthermore, in Bergamo there seems to be a mismatch between the location of loading and unloading bays and the shops while in Luxembourg the issue concerns the narrow time window exclusively dedicated to deliveries operations. As a consequence, in both cities emerged the need to review the loading/unloading bays layout and policies. 


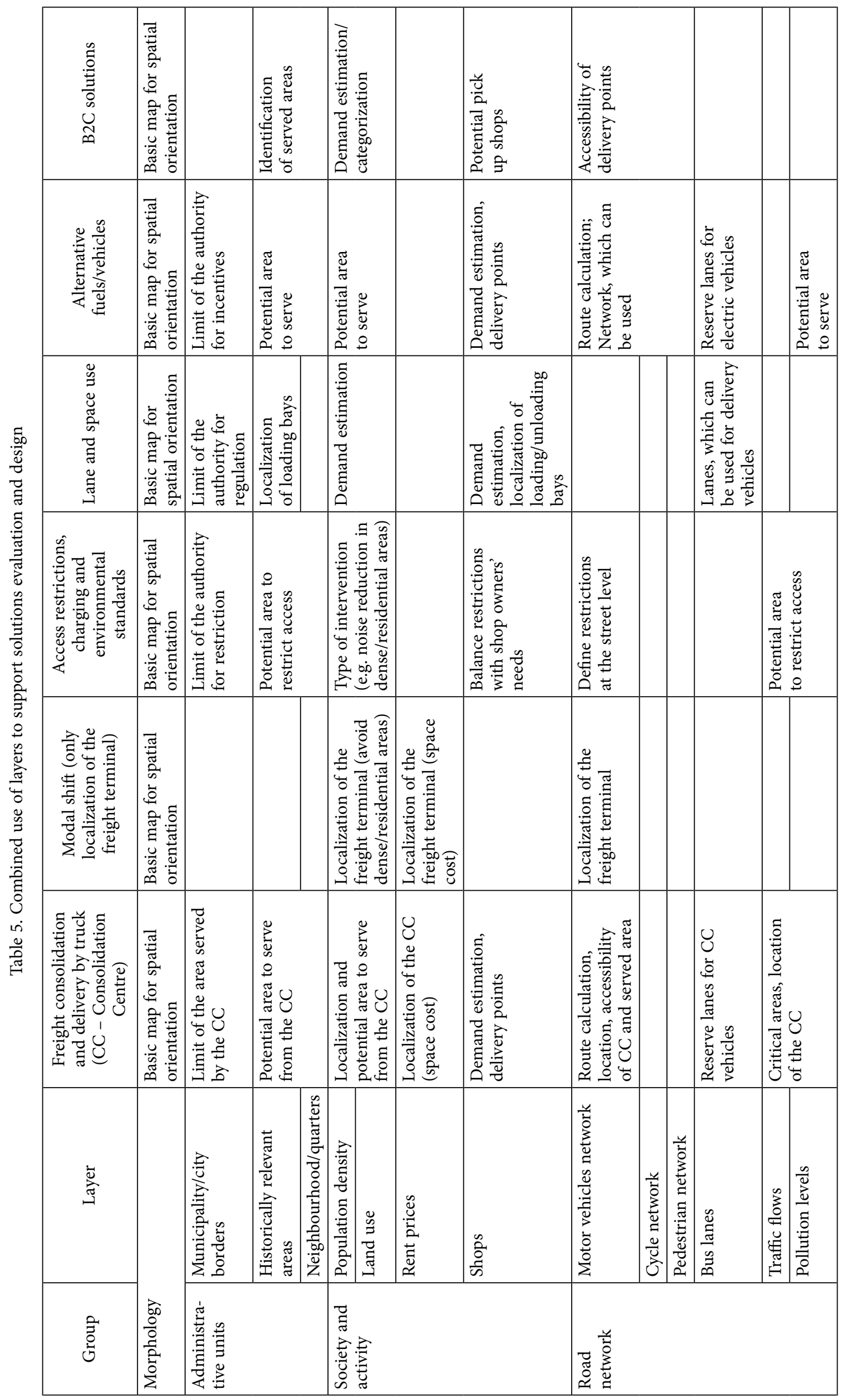




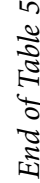

\begin{tabular}{|c|c|c|c|c|c|c|c|c|c|c|c|c|c|}
\hline 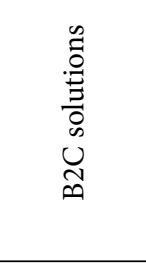 & \multicolumn{3}{|l|}{ 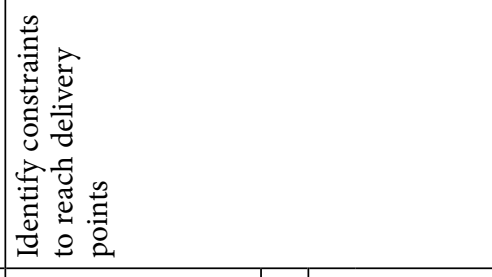 } & & & 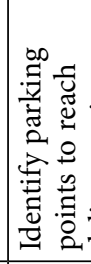 & & & 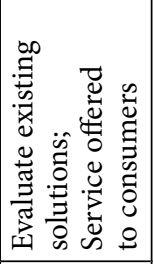 & & 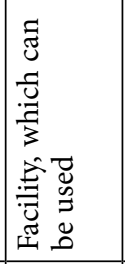 & & \\
\hline 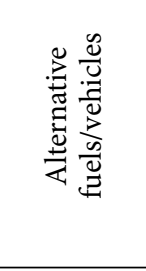 & 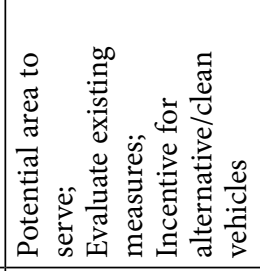 & & 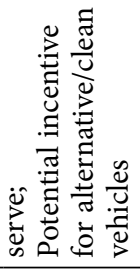 & & 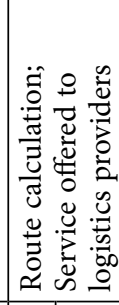 & \multicolumn{2}{|c|}{ 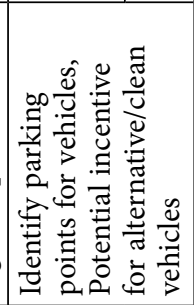 } & & & & & & \\
\hline 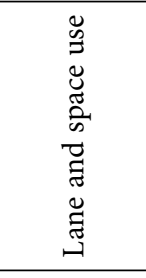 & 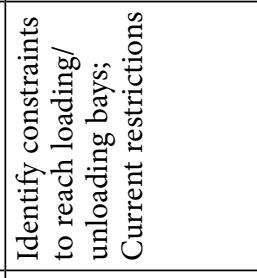 & \multicolumn{2}{|c|}{ 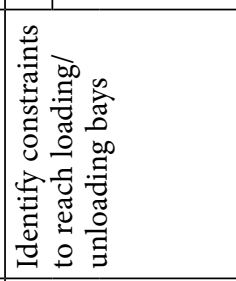 } & & & \multicolumn{2}{|c|}{ 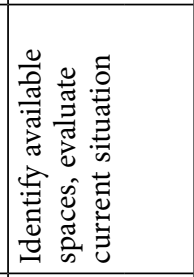 } & 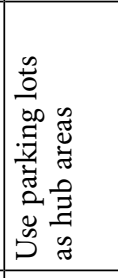 & & 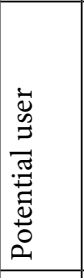 & & & \\
\hline 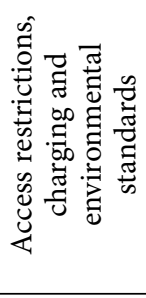 & 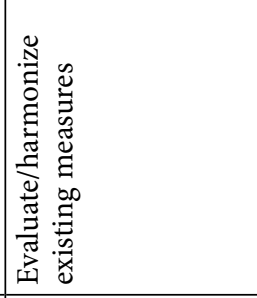 & \multicolumn{2}{|l|}{ 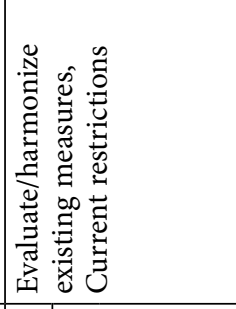 } & & & \multicolumn{2}{|l|}{ 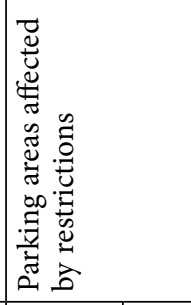 } & 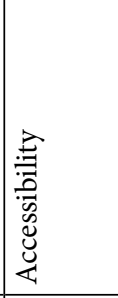 & & & & & \\
\hline 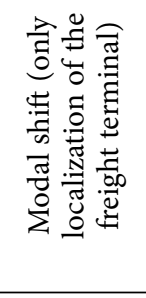 & & & & 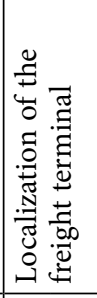 & & & & & & 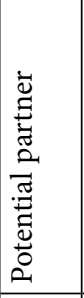 & 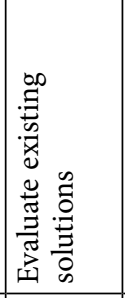 & 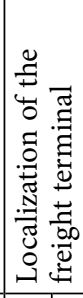 & \\
\hline 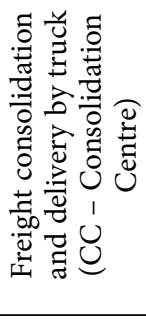 & \multicolumn{3}{|l|}{ 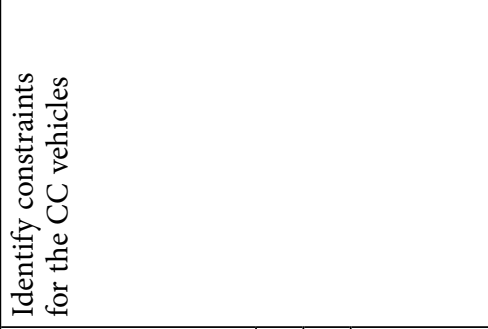 } & 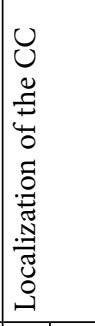 & & \multicolumn{2}{|l|}{ 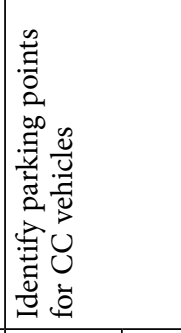 } & 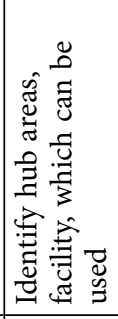 & & 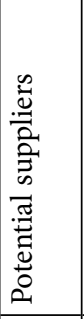 & 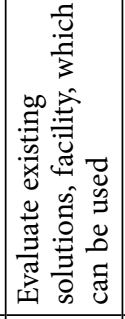 & 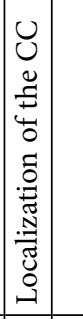 & \\
\hline 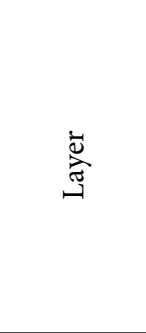 & 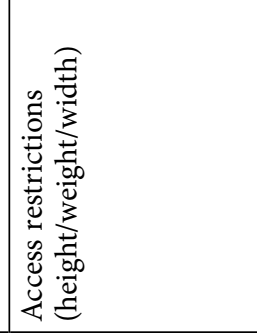 & 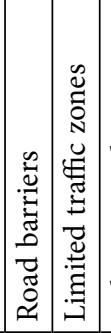 & 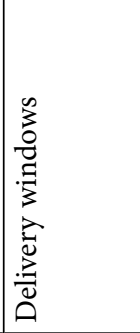 & 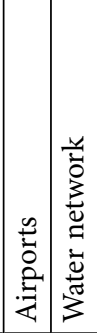 & 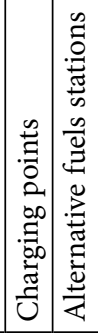 & 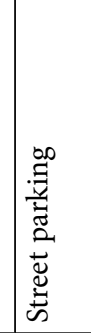 & 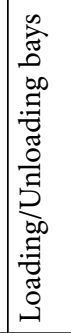 & 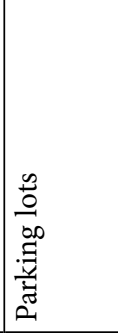 & 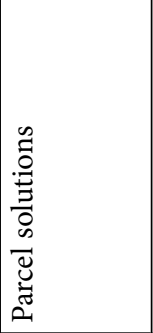 & 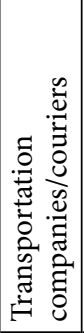 & 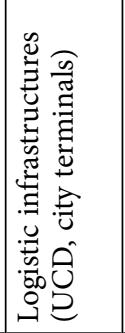 & 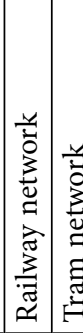 & 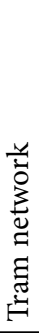 \\
\hline 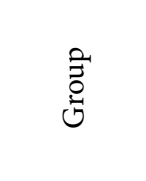 & 竞 & & & 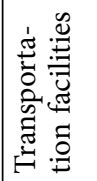 & & & & & 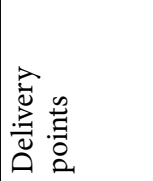 & & & 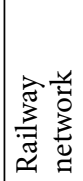 & 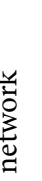 \\
\hline
\end{tabular}


For the future developments, each solution will be evaluated in detail by the research teams in collaboration with the stakeholders. For brevity sake, we do not enter in the detail of how these solutions were identified and prioritized, as our focus in this paper is on the framework that enabled such outcomes.

\section{Conclusions}

A better understanding of the city's context and stakeholder engagement are essential to propose adequate solutions in the field of UFT. However, collecting and sharing information with decision makers is a complex and time consuming task.

The framework presented in this paper allows the identification and evaluation of the most important dimensions affecting UFT, designed with the specific objective to enable stakeholder engagement and solution identification. The framework also supports the comparison between cities to foster the discussion and the UFT solutions to benchmark.

The framework is designed to exploit as much as possible open data, such as OSM data for infrastructures and commercial activities. The organization of the data and information in layers supports the understanding, analysis and discussion between stakeholders.

To show its use, the framework was applied on two cities (Bergamo and Luxembourg). The cases helped to assess the quality and reliability of the information retrieved and demonstrated the ability of the framework to identify and make comparable the different features of a city. Moreover, the cases proofed that a visual tool derived from the framework can be of great help to engage stakeholders in the early phases of the design of UFT solutions. Finally, the cases helped to understand which data from the framework can be more helpful in the analysis of specific UFT solutions, hence providing a practical example for future users.

In conclusion, building up on previous literature and case studies, this paper provides a standard framework for supporting the data collection, comparison and stakeholder engagement. Because of this, our work can be particularly useful for both researchers and decision makers working in cities still at the beginning of their city logistic journey. However, even more advanced cities could benefit from our insights in order to enrich their data sources and benchmark against other cities.

Our framework is subject to several limitations that we plan to overcome by including an analysis of the traffic, provide a set of quantitative indicators for the different features, enrich the list of features, and develop demand estimation models based on the collected information. Moreover, we purposefully excluded large retailers and supermarkets that have their own distribution systems in place. However, they are an important part of the picture when considering the demand, traffic and interactions with the other solutions. For instance, some retailers can host parcel lockers in their stores or parking lots. Because of this, we envision our framework as a platform, open to future technological advancements (e.g., new available data sources, new solutions) and new case studies so to have a growing library of shared experiences. Finally, the framework should be tested on additional cities, from small to large sized cities and with additional features such as construction logistics to validate its robustness and complete the list of city's characteristics and potential sources.

\section{Contribution}

All the authors contributed equally to the development and writing of the paper.

\section{Disclosure statement}

Authors declare they have no competing financial, professional, or personal interests from other parties.

\section{References}

Alho, A. R.; Silva, J. A. 2015. Utilizing urban form characteristics in urban logistics analysis: a case study in Lisbon, Portugal, Journal of Transport Geography 42: 57-71. https://doi.org/10.1016/j.jtrangeo.2014.11.002

Allen, J.; Browne, M.; Cherrett, T. 2012. Investigating relationships between road freight transport, facility location, logistics management and urban form, Journal of Transport Geography 24: 45-57. https://doi.org/10.1016/j.jtrangeo.2012.06.010

Álvarez, E.; De La Calle, A. 2011. Sustainable practices in urban freight distribution in Bilbao, Journal of Industrial Engineering and Management 4(3): 538-553. https://doi.org/10.3926/jiem.2011.v4n3.p538-553

Ambrosini, C.; Routhier, J.-L. 2004. Objectives, methods and results of surveys carried out in the field of urban freight transport: an international comparison, Transport Reviews 24(1): 57-77. https://doi.org/10.1080/0144164032000122343

Anderson, S.; Allen, J.; Browne, M. 2005. Urban logistics - how can it meet policy makers' sustainability objectives?, Journal of Transport Geography 13(1): 71-81. https://doi.org/10.1016/j.jtrangeo.2004.11.002

Benjelloun, A.; Crainic, T. G.; Bigras, Y. 2010. Towards a taxonomy of city logistics projects, Procedia - Social and Behavioral Sciences 2(3): 6217-6228. https://doi.org/10.1016/j.sbspro.2010.04.032

Bjerkan, K. Y.; Sund, A. B.; Nordtømme, M. E. 2014. Stakeholder responses to measures green and efficient urban freight, $R e$ search in Transportation Business \& Management 11: 32-42. https://doi.org/10.1016/j.rtbm.2014.05.001

Cherrett, T.; Allen, J.; McLeod, F.; Maynard, S.; Hickford, A.; Browne, M. 2012. Understanding urban freight activity - key issues for freight planning, Journal of Transport Geography 24: 22-32. https://doi.org/10.1016/j.jtrangeo.2012.05.008

Dablanc, L. 2007. Goods transport in large European cities: difficult to organize, difficult to modernize, Transportation Research Part A: Policy and Practice 41(3): 280-285. https://doi.org/10.1016/j.tra.2006.05.005

Dablanc, L.; Diziain, D.; Levifve, H. 2011. Urban freight consultations in the Paris region, European Transport Research Review 3(1): 47-57. https://doi.org/10.1007/s12544-011-0049-2 
Deflorio, F. P.; Gonzalez-Feliu, J.; Perboli, G.; Tadei, R. 2012. The influence of time windows on the costs of urban freight distribution services in city logistics applications, European Journal of Transport and Infrastructure Research 12(3): 256-274.

Ducret, R. 2014. Parcel deliveries and urban logistics: Changes and challenges in the courier express and parcel sector in Europe - the French case, Research in Transportation Business \& Management 11: 15-22.

https://doi.org/10.1016/j.rtbm.2014.06.009

EC. 2007. Directive 2007/2/EC of the European Parliament and of the Council of 14 March 2007 Establishing an Infrastructure for Spatial Information in the European Community (INSPIRE). 14 p. Available from Internet: https://eur-lex.europa.eu/legalcontent/EN/ALL/?uri=CELEX:32007L0002

EC. 2011. White Paper: Roadmap to a Single European Transport Area - Towards a Competitive and Resource Efficient Transport System. COM(2011) 144 final. 28.3.2011, Brussels. Available from Internet: http://eur-lex.europa.eu/legal-content/EN/ ALL/?uri=CELEX:52011DC0144

ERTRAC. 2014. Urban Freight Research Roadmap. European Road Transport Research Advisory Council (ERTRAC). 60 p. Available from Internet: https://www.ertrac.org/uploads/documentsearch/id36/ERTRAC_Alice_Urban_Freight.pdf

Flamini, M.; Nigro, M.; Pacciarelli, D. 2011. Assessing the value of information for retail distribution of perishable goods, $\mathrm{Eu}$ ropean Transport Research Review 3(2): 103-112. https://doi.org/10.1007/s12544-011-0051-8

Gatta, V.; Marcucci, E. 2015. An interactive multi-actor multicriteria analysis: a case study for alternative off-peak delivery solutions in freight distribution in Rome, in Proceedings of the URBE 2015: Urban Freight and Behavior Change, 1-2 October 2015, Rome, Italy.

Gatta, V.; Marcucci, E. 2014. Urban freight transport and policy changes: Improving decision makers' awareness via an agentspecific approach, Transport Policy 36: 248-252.

https://doi.org/10.1016/j.tranpol.2014.09.007

Gruber, J.; Kihm, A.; Lenz, B. 2014. A new vehicle for urban freight? An ex-ante evaluation of electric cargo bikes in courier services, Research in Transportation Business \& Management 11: 53-62. https://doi.org/10.1016/j.rtbm.2014.03.004

Guerlain, C.; Cortina, S.; Renault, S. 2016. Towards a collaborative geographical information system to support collective decision making for urban logistics initiative, Transportation Research Procedia 12: 634-643. https://doi.org/10.1016/j.trpro.2016.02.017

Hesse, M. 2004. Logistics and freight transport policy in urban areas: a case study of Berlin-Brandenburg/Germany, European Planning Studies 12(7): 1035-1053.

https://doi.org/10.1080/0965431042000267894

Holguín-Veras, J. 2008. Necessary conditions for off-hour deliveries and the effectiveness of urban freight road pricing and alternative financial policies in competitive markets, Transportation Research Part A: Policy and Practice 42(2): 392-413. https://doi.org/10.1016/j.tra.2007.10.008

Joubert, J. W.; Fourie, P. J.; Axhausen, K. W. 2010. Large-scale agent-based combined traffic simulation of private cars and commercial vehicles, Transportation Research Record: Journal of the Transportation Research Board 2168: 24-32. https://doi.org/10.3141/2168-04

Kittelson, W.; Lawton, T. 1987. Evaluation of shopping center trip types, ITE Journal (2): 35-39.

Lagorio, A.; Pinto, R.; Golini, R. 2016. Research in urban logistics: a systematic literature review, International Journal of Physical Distribution \& Logistics Management 46(10): 908931. https://doi.org/10.1108/IJPDLM-01-2016-0008
Lian, J. I. 2008. The Oslo and Bergen toll rings and road-building investment - effect on traffic development and congestion, Journal of Transport Geography 16(3): 174-181. https://doi.org/10.1016/j.jtrangeo.2007.08.004

Lindawati, L.; Van Schagen, J.; Goh, M.; De Souza, R. 2014. Collaboration in urban logistics: motivations and barriers, International Journal of Urban Sciences 18(2): 278-290. https://doi.org/10.1080/12265934.2014.917983

Lindholm, M. 2014. Successes and failings of an urban freight quality partnership - the story of the Gothenburg local freight network, Procedia - Social and Behavioral Sciences 125: 125-135. https://doi.org/10.1016/j.sbspro.2014.01.1461

Lindholm, M.; Behrends, S. 2012. Challenges in urban freight transport planning - a review in the Baltic Sea region, Journal of Transport Geography 22: 129-136.

https://doi.org/10.1016/j.jtrangeo.2012.01.001

Lüer-Villagra, A.; Marianov, V. 2013. A competitive hub location and pricing problem, European Journal of Operational Research 231(3): 734-744.

https://doi.org/10.1016/j.ejor.2013.06.006

Macharis, C.; Milan, L.; Verlinde, S. 2014. A stakeholder-based multicriteria evaluation framework for city distribution, $R e$ search in Transportation Business \& Management 11: 75-84. https://doi.org/10.1016/j.rtbm.2014.06.004

McLeod, F.; Cherrett, T. 2011. Loading bay booking and control for urban freight, International Journal of Logistics Research and Applications: a Leading Journal of Supply Chain Management 14(6): 385-397.

https://doi.org/10.1080/13675567.2011.641525

Mohajeri, N.; Gudmundsson, A.; French, J. R. 2015. $\mathrm{CO}_{2}$ emissions in relation to street-network configuration and city size, Transportation Research Part D: Transport and Environment 35: 116-129. https://doi.org/10.1016/j.trd.2014.11.025

Morganti, E.; Dablanc, L.; Fortin, F. 2014. Final deliveries for online shopping: the deployment of pickup point networks in urban and suburban areas, Research in Transportation Business \& Management 11: 23-31.

https://doi.org/10.1016/j.rtbm.2014.03.002

Muñuzuri, J.; Cortés, P.; Guadix, J.; Onieva, L. 2012. City logistics in Spain: why it might never work, Cities 29(2): 133-141. https://doi.org/10.1016/j.cities.2011.03.004

Muñuzuri, J.; Larrañeta, J.; Onieva, L.; Cortés, P. 2005. Solutions applicable by local administrations for urban logistics improvement, Cities 22(1): 15-28.

https://doi.org/10.1016/j.cities.2004.10.003

Nuzzolo, A.; Crisalli, U.; Comi, A. 2015. An aggregate transport demand model for import and export flow simulation, Transport 30(1): 43-54. https://doi.org/10.3846/16484142.2013.820215

Olsson, J.; Woxenius, J. 2014. Localisation of freight consolidation centres serving small road hauliers in a wider urban area: barriers for more efficient freight deliveries in Gothenburg, Journal of Transport Geography 34: 25-33. https://doi.org/10.1016/j.jtrangeo.2013.10.016

Pino, E. M.; San Nicolás, D.; Espinós, I. 2014. DOROTHY project: urban logistics organization in Valencian community, Procedia - Social and Behavioral Sciences 160: 420-429. https://doi.org/10.1016/j.sbspro.2014.12.154

Pulawska, S.; Starowicz, W. 2014. Ecological urban logistics in the historical centers of cities, Procedia - Social and Behavioral Sciences 151: 282-294.

https://doi.org/10.1016/j.sbspro.2014.10.026 
Quak, H. J.; De Koster, M. B. M. 2009. Delivering goods in urban areas: how to deal with urban policy restrictions and the environment, Transportation Science 43(2): 211-227.

https://doi.org/10.1287/trsc.1080.0235

Quak, H. J.; De Koster, M. B. M. 2007. Exploring retailers' sensitivity to local sustainability policies, Journal of Operations Management 25(6): 1103-1122.

https://doi.org/10.1016/j.jom.2007.01.020

Regué, R.; Bristow, A. L. 2013. Appraising freight tram schemes: a case study of Barcelona, European Journal of Transport and Infrastructure Research 13(1): 56-78.

Russo, F.; Comi, A., 2011. A model system for the ex-ante assessment of city logistics measures, Research in Transportation Economics 31(1): 81-87.

https://doi.org/10.1016/j.retrec.2010.11.011

Schneider, M.; Stenger, A.; Goeke, D. 2014. The electric vehiclerouting problem with time windows and recharging stations, Transportation Science 48(4): 500-520. https://doi.org/10.1287/trsc.2013.0490

Stenger, A.; Vigo, D.; Enz, S.; Schwind, M. 2013. An adaptive variable neighborhood search algorithm for a vehicle routing problem arising in small package shipping, Transportation Science 47(1): 64-80. https://doi.org/10.1287/trsc.1110.0396

Van Rooijen, T.; Quak, H. 2014. City logistics in the European CIVITAS initiative, Procedia - Social and Behavioral Sciences 125: 312-325. https://doi.org/10.1016/j.sbspro.2014.01.1476

Walker, G.; Manson, A. 2014. Telematics, urban freight logistics and low carbon road networks, Journal of Transport Geography 37: 74-81. https://doi.org/10.1016/j.jtrangeo.2014.04.006

Wang, X.; Zhan, L.; Ruan, J.; Zhang, J. 2014. How to choose "last mile" delivery modes for e-fulfillment, Mathematical Problems in Engineering 2014: 1-11.

https://doi.org/10.1155/2014/417129

Witkowski, J.; Kiba-Janiak, M. 2014. The role of local governments in the development of city logistics, Procedia - Social and Behavioral Sciences 125: 373-385. https://doi.org/10.1016/j.sbspro.2014.01.1481

Yang, Z. Z.; Moodie, D. R. 2011. Locating urban logistics terminals and shopping centres in a Chinese city, International Journal of Logistics Research and Applications: a Leading Journal of Supply Chain Management 14(3): 165-177.

https://doi.org/10.1080/13675567.2011.609159 